\title{
ON THE WAY TO OBSERVE HOW FUTURE PRIMARY SCHOOL TEACHERS REASON ABOUT FRACTIONS
}

Libuše Samkován $^{\bowtie}$, Marie Tichá ${ }^{2}$

${ }^{\triangle 1}$ Faculty of Education, University of South Bohemia, Jeronýmova 10, 375 15, České Budějovice, Czech Republic, 1samkova@pf.jcu.cz

${ }^{2}$ Department of Didactics of Mathematics, Institute of Mathematics of the Czech Academy of Sciences, Czech Republic

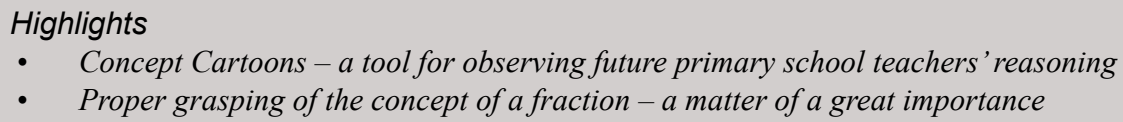

Article type

Full research paper

Article history

Received: April 25, 2017

Received in revised form: December 4, 2017

Accepted: December 6, 2017

Available on-line: December 20, 2017

\section{Keywords}

Concept Cartoons; fractions; future primary school teachers; problem solving; problem posing; reasoning

Samková L., Tichá M. (2017) “On The Way to Observe How Future Primary School Teachers Reason about Fractions”, Journal on Efficiency and Responsibility in Education and Science, Vol. 10, No. 4, pp. 93-100, online ISSN 1803-1617, printed ISSN 23362375, doi: 10.7160/eriesj.2017.100401.

\section{Introduction}

The study reported here is a part of a three-year qualitative educational research conducted under Czech Science Foundation project. The goal of the project is to implement inquiry-based education into university courses on mathematics and didactics of mathematics for future primary school teachers, and observe how active participation in these courses can influence professional competences of project participants, i.e. their knowledge, beliefs, and practice. In this particular study we focus on potentiality of an educational tool called Concept Cartoons, a tool which we use as diagnostic in the project.

In our last year's ERIE contribution (Samková and Tichá, 2016a) we focused on the possibility to develop project participants' open approach to mathematics during the course on mathematics, and introduced Concept Cartoons as a diagnostic instrument in the referred study. In particular, we used Concept Cartoons during problem solving activities to observe whether the participants of the study searched for different solutions of a given problem, and whether they accepted different forms of notations of a given solution. Lately, in the extended version of the contribution that was published in the ERIES Journal (Samková and Tichá, 2016c), we also used Concept Cartoons as a diagnostic instrument during problem posing activities in order to observe whether the participants of the study were able to pose Concept Cartoons that could allow their pupils to experience open approach to mathematics.

Now we investigate other opportunities related to using Concept Cartoons in future primary school teachers' education, and introduce Concept Cartoons as an instrument for observing future primary school teachers' reasoning. As a mathematical topic in the centre of the study we choose fractions, a topic that is just on the boundary between primary and lower-secondary school curricula in the Czech Republic, since the concept of a fraction per se belongs to the primary school curriculum (curriculum for pupils' age 6 to 11), and issues related to operations on fractions belong to the lower-secondary school curriculum (pupils' age 11 to 15). Again, we focus on problem solving and problem posing activities.

Our research questions are "What kinds of reasoning about fractions can be observed in future primary school teachers when using Concept Cartoons as a diagnostic instrument during problem solving?" and "What kinds of reasoning about fractions can be observed in future primary school teachers when using Concept Cartoons as a diagnostic instrument during problem posing?"

For the purpose of the research on the first research question we shall take a task on fractions belonging to primary school level, and adapt it to the Concept Cartoon form. We shall assign the adapted task to future primary school teachers, and observe how they reason when solving the task. For the purpose of the research on the second research question we shall ask future primary school teachers to pose tasks in the form of Concept Cartoons, and observe how they reason when posing the task.

The topic of fractions belongs to the most difficult ones, both in primary and secondary school context; many empirical researchers point out that (future) teachers tend to have only limited knowledge about this topic (Cramer and Lesh, 1988; Ma, 1999; Tirosh, 2000; Depaepe et al., 2015; Singer, Ellerton and Cai, 2015). The limitations refer to content knowledge as well as pedagogical content knowledge, so that our contribution addresses both these aspects.

From the perspective of ERIE conferences and ERIES Journal, the topic of our contribution is in relation to educational issues 
such as students' ability to solve mathematical problems (Novotná et al., 2014; Novotná, 2016), pupils' academic efficacy in the course of transition between primary and secondary school levels (Hoskovcová and Krejčová, 2015), or assessment in inquiry based primary mathematics (Hošpesová and Žlábková, 2016). Moreover, the study deals with problem posing which is in relation to teachers' ability to pose mathematical problems (Patáková, 2013).

The paper has been developed as an extension of the contribution (Samková and Tichá, 2017b). At the beginning it presents background to the topic of fractions in the primary school classroom, and introduces participants of the study and employed tools (Concept Cartoons, problem posing). Then follows the description of the course of the research, and its results.

\section{Fractions in the primary school classroom}

As mentioned above, the part of the fractions topic belonging to the primary school mathematics in the Czech Republic consists of the concept of a fraction per se. The fundamental interpretation of fractions is the part-whole interpretation which is based on partitioning either a continuous quantity or a set of discrete objects into equal-sized subparts or sets (Behr et al., 1983), the continuous quantity might also be indicatively prepartitioned (Lamon, 2006).

So that the primary school teachers and pupils meet usually tasks requiring

- to match fractions with various continuous models (e.g. to colour a fractional part of a shape, to ascertain which part of a shape is coloured, to ascertain a whole for a given fractional part of a shape, to find a fractional part by paper-folding, etc.); for samples see Figure 1 (prepartitioned model) and Figure 2;

- to match fractions with various discrete models (e.g. to colour a fractional part of a set of discrete objects, to ascertain which part of the set is coloured, to ascertain a whole for a given fractional part of the set, etc.), for a sample see Figure 3;

- to compare fractions using the models; for a sample see Figure 4.

The models used for this purpose may be linear, planar, and also spatial. Being on the primary school level, models that use manipulatives are the first in line - pupils may use scissors, do paper-folding, glue coloured papers together, manage mosaics, marbles or cubes, etc.
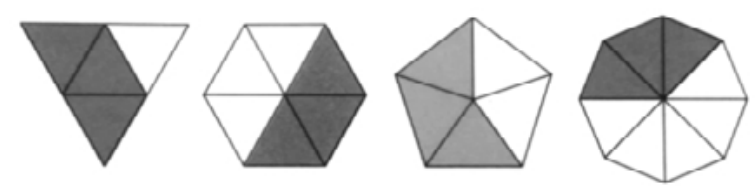

Figure 1: „Name by a fraction what part of the shape is coloured.“ (source: Divíšek, Hošpesová and Kuřina, 1999: 100; own translation)

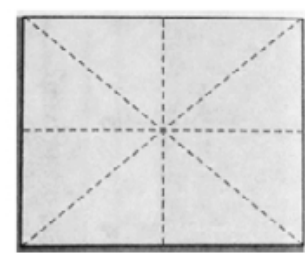

Figure 2: „Divide by folding a sheet of paper into eights.“ (source: Divíšek, Hošpesová and Kuřina, 1999: 93; own translation)

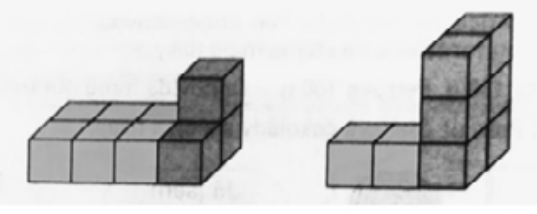

Figure 3: „a) Use yellow and blue cubes to build the building by the picture. b) Write by a fraction what part of the cubes in the building is blue. c) Add or remove some cubes, so that the blue cubes form $1 / 3$ of all the cubes in the building." (source: Koman, Kuřina and Tichá, 1997: 8; own translation)
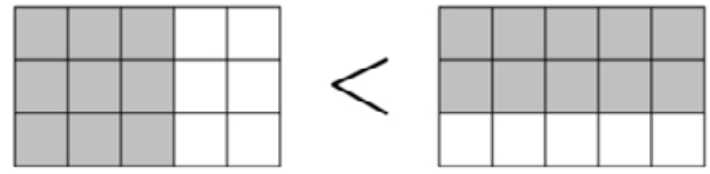

Figure 4: „What is more: $3 / 5$ or $2 / 3$ ? “ - a graphical solution (source: own GeoGebra construction)

Primary school teachers and pupils can also meet more complex tasks that combine several different fractions (either with the same whole for all given fractions, or with different wholes for particular fractions), or tasks that are based on one or more fractional changes:

There were 16 cakes on a plate. Petra ate a quarter of them, Michal ate a half, and Eva ate the rest. How many cakes ate Eva? (Divíšek, Hošpesová and Kuřina, 1999: 119; own translation)

In the beginning of the season, the price of peppers was 72 crowns per kilogram. In the middle of the season, the price has fallen by half. In the end of the season, the price again grew, by half of the new price. What was the price in the middle and in the end of the season? (Koman, Kurrina and Tichá, 1997: 124; own translation)

Some rather difficult non-standard tasks based on the concept of a fraction can be found in entrance exams to lower-secondary selective schools, i.e. in exams that are taken by pupils in the last year of primary school level (pupils' age 10 to 11 ):

A half of the ketchup in a bottle is already consumed, and the bottle with the ketchup weighs $690 \mathrm{~g}$. After dinner, at which the family consumed a half of the remaining amount of the ketchup, the bottle with ketchup weighs only $430 \mathrm{~g}$. What is the weight of the ketchup in a full bottle? What is the weight of an empty bottle? (Brlicová, Vémolová and Zelený, 2016: 23; own translation)

Lumberjacks cut up the trunk of a spruce. A half of the logs were one-meter-long, a quarter of the logs were $75-\mathrm{cm}$ long, and the remaining 2 meters were cut to logs half-ameter long. How long was the trunk of the spruce? (ibid: 69; own translation).

Some non-standard tasks based just on the concept of a fraction can be occasionally found also in newspapers, in a recreational mathematics column:

There are 700 adults in a village where $1 / 3$ of women is married to $1 / 4$ of men. How many women and how many men live in the village? ${ }^{1}$

To solve such tasks, the pupil (as well as the teacher) has to be well oriented in the described situation, and has to decide properly what are the parts and the wholes of the situation. Generally said, the decision about what is the whole in a task is the crucial one, and we shall focus on this issue from the

$1 \quad$ Very similar but much more difficult task that no longer belongs to primary school mathematics is presented by Lamon (2006: 12): "What is the ratio of men to women in the town where $2 / 3$ of the men are married to $3 / 4$ of the women?" 
perspective of future primary school teachers. An inability to identify the whole causes many misconceptions and wrong solutions, not only within the topic of fractions but also in many others. This is because the reasoning employed when working with fractions serves as an important base for reasoning in other mathematical topics, namely percentages - a topic that is widely applicable in our everyday life, with high impact on personal financial issues:

Is it better to have $30 \%$ coffee extra free or a $25 \%$ discount on the price of a jar? (Littler and Tylor-Basil, 1999: 76)

The inability to identify the whole often causes misconceptions also during problem posing; typical examples of such misconceptions were presented e.g. by Hošpesová and Tichá (2015) who asked in-service and pre-service teachers to pose several word problems including fractions $1 / 2$ and $3 / 4$, and, among others, received the following responses:

Dad decorated $1 / 2$ of the guest-room. Granddad decorated $3 / 4$ of the living room. Who decorated more and how much more? (ibid: 440)

There were 20 passengers on a plane. $3 / 4$ of the passengers left the plane during the stopover, $1 / 2$ boarded the plane. How many passengers continued the journey? (ibid: 440)

\section{Materials and Methods \\ Participants}

The referred study relates mainly to a group of respondents we have been observing systematically on a long-term basis. We will call them long-term participants. These respondents are 31 future primary school teachers, completely all students of the third year of five-year master degree program at the Faculty of Education, University of South Bohemia in České Budějovice. ${ }^{2}$ During the academic year that preceded the referred study, the long-term participants had successfully completed their mathematics content course, and in the time of the referred study they were attending a subsequent course on didactics of mathematics.

Each of the long-term participants had been randomly assigned a unique code number. The code numbers had been chosen from the range between 1 and 39, to provide anonymity not only for the initial group of long-term participants but also for potential newcomers. In such a setting, not all of the numbers from 1 to 39 had been used, so that a newcomer did not obtain automatically the biggest number but one of the smaller ones that had not been assigned yet.

Some of the tasks discussed in this paper were also occasionally assigned to other groups of participants: future primary school teachers from the same university and the same study year but another academic year, or future lower-secondary school teachers from other universities (Faculty of Education, Charles University in Prague, and Institute of Mathematics, Pedagogical University of Cracow, Poland). We will call them additional participants. Results related to additional participants will be also discussed in the study, to obtain a more complex overview of the reported issue. Data collected from 78 future lowersecondary school teachers will provide an illustration to the first part of the study, and data collected from 36 additional future primary school teachers will enrich the second part of the study.

\section{Diagnostic instrument}

As a diagnostic instrument in our study we use again the educational tool called Concept Cartoons (Keogh and Naylor,

2 In the Czech Republic, future primary school teachers are not math specialists; after graduation they are expected to teach all primary school subjects. They are supposed to study a four or five-year master degree program designed especially for future primary school teachers.
1999). Each Concept Cartoon is a picture showing a group of several children in a bubble-dialog, where individual children present alternative viewpoints on the displayed situation, e.g. opinions, statements, proposals of ways of solving, possible results (see Figure 5). The alternatives may be correct as well as incorrect; their correctness may also be unclear or conditional. Concept Cartoons and their history were introduced in detail in our previous contributions (Samková and Tichá, 2016a, 2016c; Samková, 2016a), various samples of Concept Cartoons may be found there.
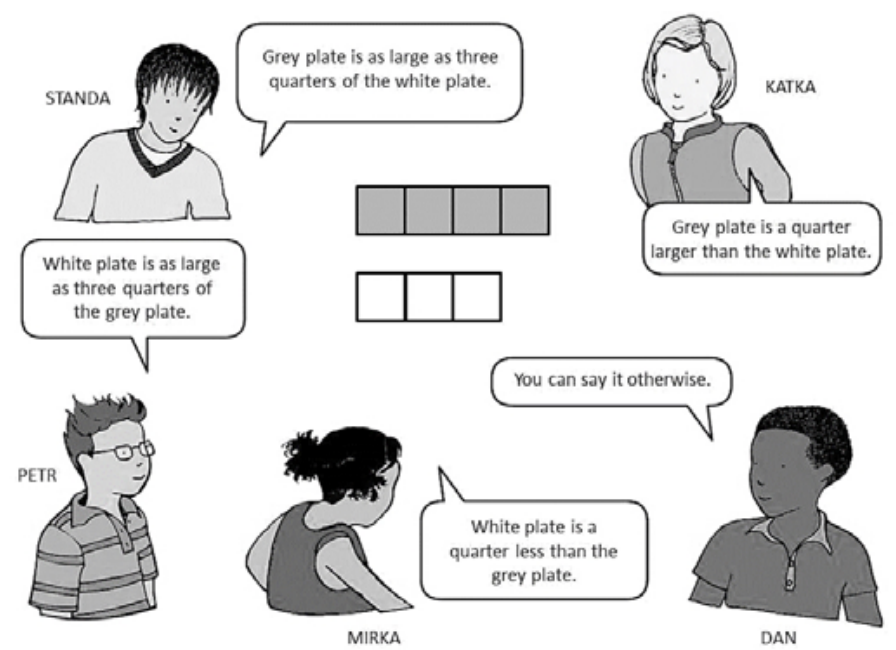

Figure 5: Concept Cartoon on fractions, own translation (source of the template of children with empty bubbles: Dabell, Keogh and Naylor, 2008: 5.9)

Our recent research showed that the tool may be widely employed in future primary school teachers' education: besides identifying the aspects related to open approach to mathematics (Samková and Tichá, 2016a, 2016c), we used it also for identifying various aspects of the process of grasping of a situation (Samková and Tichá, 2015), for distinguishing between procedural and conceptual knowledge (Samková and Hošpesová, 2015), as an instrument promoting the awareness of the need of proper argumentation and leading towards deductive argumentation (Samková and Tichá, 2016b), for investigating pedagogical content knowledge (Samková, 2016a, 2016b), or for observing reasoning on pattern generalization (Samková and Tichá, 2017a).

Another instrument used in this study is problem posing. We have been using it in future teachers' education for more than 10 years, as an educational, motivational and diagnostic tool (Tichá and Hošpesová, 2013; Hošpesová and Tichá, 2015), and we are convinced that it can lead future teachers to deeper understanding of mathematical topics as well as to enhancement of their pedagogical content knowledge.

Recently, we have often combined Concept Cartoons and problem posing together, to get another perspective on future teachers' reasoning and pedagogical content knowledge: by combining the two instruments we already observed future teachers' open approach to mathematics (Samková and Tichá, 2016c), and reasoning during pattern generalization (Samková and Tichá, 2017a).

\section{First part of the research: Concept Cartoons and problem solving}

The first part of the research relates to problem solving. It aspires to look for answers to the research question "What kinds of reasoning about fractions can be observed in future primary school teachers when using Concept Cartoons as a diagnostic instrument during problem solving?" 
In this part of the research, data collection took part in several independent stages during the academic year. Each time we assigned the respondents (long-term participants) a worksheet with a Concept Cartoon focusing on the topic of fractions, and asked them to decide which children in the picture are right and which are wrong, and to justify the decision. For the purpose of data collection, the participants worked on the worksheets individually, during the lesson.

For the study referred here we choose the Concept Cartoon shown in Figure 5. The task behind this picture concentrates on the parts-and-whole decision from various perspectives, since it is based on comparing two pre-partitioned models with diverse wholes. This Concept Cartoon has two correct bubbles (Petr, Mirka), two incorrect bubbles (Standa, Katka), and one open bubble indirectly inviting respondents to present their own opinions on the pictured situation (Dan). We assigned the Concept Cartoon to long-term participants in the time before the topic of fractions was discussed at the didactical course. The Concept Cartoon was also independently assigned to 78 additional participants - future lower-secondary school teachers from Prague and Cracow.

During data analysis we registered combinations of bubbles that were chosen by individual respondents as right, and combinations of bubbles that were chosen as wrong. Afterwards we also analysed which kinds of reasoning appeared in justifications presented in the worksheets.

\section{Second part of the research: Concept Cartoons and problem posing}

The second part of the research relates to problem posing. It extends the first part of the research, and aspires to look for answers to the research question "What kinds of reasoning about fractions can be observed in future primary school teachers when using Concept Cartoons as a diagnostic instrument during problem posing?"

In this part of the research, data collection took place in one stage. For the long-term participants it was several months after the first part of the research, in the time after the topic of fractions was discussed at the didactical course. The group of additional participants for this part of the research consisted of future primary school teachers from the same university and the same study year but different academic year; those did not attend the first part of the research.

We asked the participants to create their own Concept Cartoon that could be assigned to primary school pupils during a lesson on mathematics. The fractions topic was neither required, nor mentioned in the assignment; the long-term participants did not know about the relation between the first and the second parts of the research.

Both long-term and additional participants worked on the task individually, in the form of a written homework; the homework was treated by 26 long-term participants, and by 36 additional participants.

During data analysis we focused again on reasoning about fractions, but this time from the perspective of problem posing. We concentrated on the nature of the alternatives offered in bubbles, and on kinds of reasoning that appeared in explanations provided by individual respondents in descriptive texts that accompanied the posed Concept Cartoons.

\section{Results}

\section{Problem solving and choice of alternatives to agree}

Initially, we observed responses from the perspective of individual alternatives given in bubbles, and without further analysis of the reasoning behind the answers. We monitored which alternatives were chosen by the respondents as the ones to agree.

From this perspective, the responses of long-term participants seemed to be rather comforting: all of the respondents correctly agreed with Petr and disagreed with Standa, majority of the respondents correctly agreed with Mirka. Just responses to Katka's bubble pointed out that the respondents might have faced some difficulties: minority of the respondents correctly disagreed with Katka. For proportional details see Figure 6.

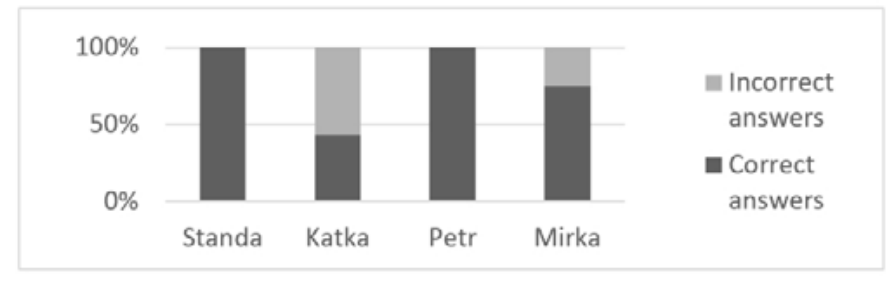

Figure 6: Answers to bubbles given by long-term participants,

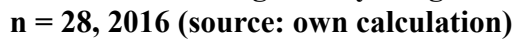

Next, we focused in detail on responses related to Mirka and Katka, and observed which combinations of agreement and disagreement appeared in worksheets. This method revealed us that the range of the difficulties might be wide: only minority of the respondents who correctly agreed with Mirka displayed also disagreement with Katka. For proportional details see Figure 7.
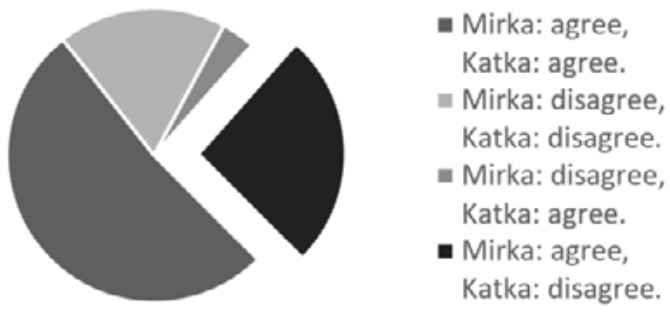

Figure 7: Combinations of answers to Mirka's and Katka's bubbles given by long-term participants; the only correct combination „Mirka: agree, Katka: disagree“ is separated, $n=28,2016$ (source: own calculation)

Also the results related to data from additional participants (future lower-secondary teachers) showed similar trends - particular proportions differed for different groups of respondents but the only correct combination always belonged to minority of respondents. See Figure 8 and Figure 9.

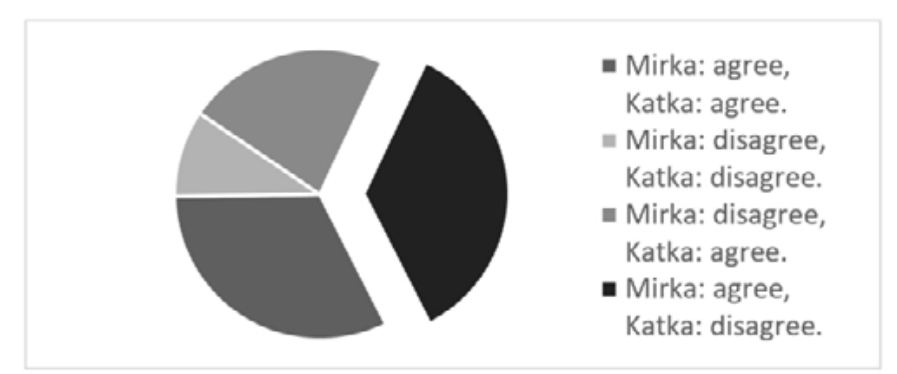

Figure 8: Combinations of answers to Mirka's and Katka's bubbles given by the additional participants from Cracow, $n=62,2016$ (source: own calculation) 


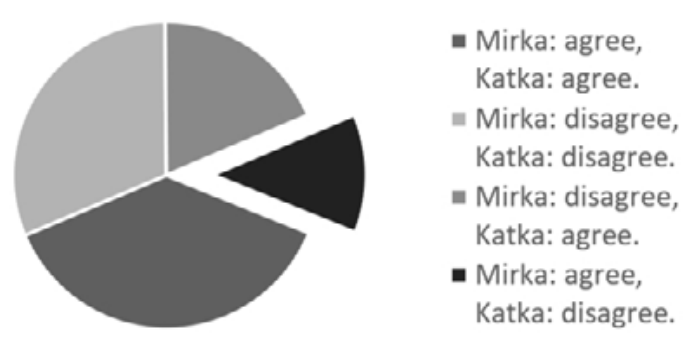

Figure 9: Combinations of answers to Mirka's and Katka's bubbles given by the additional participants from Prague, $n=16,2016$ (source: own calculation)

\section{Problem solving and kinds of reasoning}

Alarmed by the previous results, we observed more thoroughly the reasoning that led the respondents to their decisions, especially to the incorrect combinations of responses related to Mirka and Katka. The following overview and illustrative data excerpts belong to long-term participants.

Most of the incorrect responses were caused by handling fractions as an additive structure:

S16: Mirka and Katka - the same solution, just one of them used the word "less" while the other used "larger", and they swapped the plates.

by not realizing that the whole in Mirka's interpretation is not the same as the whole in Katka's interpretation:

S25: True: Katka, Mirka, Petr. They took the whole as $4 / 4$, and then matched and compared. They were thinking in fractions, and properly.

S30: Katka is true, the grey plate is a quarter of the grey plate larger. She would not be true, if she thought of it as of a quarter of the white plate.

or by handling 1/4 as a new reference unit, as a "named number" (Hruša and Vyšín, 1964):
S32: Katka - correct. ... grey $=4 / 4$
white $=3 / 4$
grey is $1 / 4$ bigger than white

Among the long-term participants there were several who saw the sources of errors in linguistics, and proposed their own corrections of texts in bubbles. Some of them considered both Katka and Mirka as incorrect:
S19: Katka - the grey plate is by its own $1 / 4$ larger than the white plate
- just more precise formulation is needed

Mirka - the white plate is smaller by $1 / 4$ of the grey plate

some considered Katka as correct and Mirka as incorrect:

S13: Katka - yes. But I would rather write "by its own quarter". Mirka - no. It is not clear by which quarter.

I would rather write "by a quarter of the grey plate".

On the other hand, majority of the respondents who correctly identified Mirka as being true and Katka as being wrong, also proposed proper reasoning in their worksheets. For instance, the respondent $\mathrm{S} 33$ who suggested to show that $1 / 4$ of the grey plate does not equal $1 / 4$ of the white plate (and accompanied the suggestion by an illustrative picture), or S2 who deemed it necessary to emphasize that even though the grey plate is compared to the white plate by $1 / 3$ larger, the white plate is compared to the grey plate by $1 / 4$ less.

\section{Problem posing, choice of alternatives to pose, and kinds of reasoning}

Among Concept Cartoons posed by the participants (both longterm and additional), we found only several that included the topic of fraction; none of them appeared in the group of longterm participants.

On the other hand, these several Concept Cartoons devoted to fractions were of decent quality, with probable and plausible pupils' misconceptions offered in bubbles, and decent explanations in the descriptive text. For illustration, we shall introduce in detail one of them - the one shown in Figure 10. This Concept Cartoon is based on a task that requires to ascertain a fractional part of a set of discrete objects ( $3 / 5$ of 30$)$, and its complement.

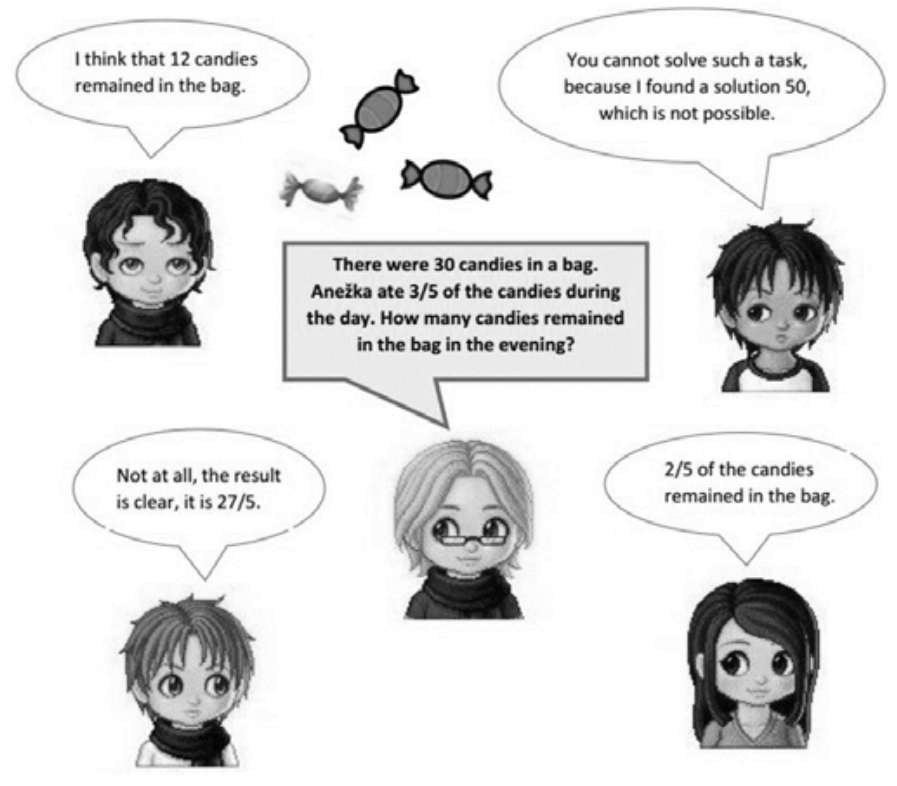

Figure 10: Concept Cartoon posed by one of the future primary school teachers; own translation (source: student work)

The top left bubble offers the correct result (12), and the descriptive text accompanying the picture explains how the child could get to the result: by determining the $3 / 5$ of 30 (by calculations $30: 5=6,3 \cdot 6=18$ ) and subtracting it from the whole $(30-18=12)$.

The bottom right bubble offers the result $2 / 5$, which is related to an alternative way of solving: it determines the complement first, in the term of fractions $(5 / 5-3 / 5=2 / 5)$. The respondent provides an additive commentary to this bubble: "This way of solving is also correct, but we do not know the precise number of candies. However, it is not exactly written in the assignment how the result should be presented." 3

The top right bubble offers a child's commentary which is based on the most frequent misconception related to the tasks requiring to ascertain a fractional part of a set of discrete objects. This misconception consists in reversing the order of numerator and denominator in the above mentioned calculations related to determining the fractional part. In case of determining $3 / 5$ of 30 the misconception leads to calculations $30: 3=10,5 \cdot 10=50$.

3 In Czech language, which is the language of our participants, we may use the same wording for the translation of "how many candies" and "how much of the candies". So that the Czech version of the question in the angular bubble really does not determine whether the result should express the number of candies or the fractional part. 
From our experience, the misconception often appears as the consequence of learning without understanding, when the pupil learns the procedure but not the concept, and so that they may make a mistake in the order of the steps of the procedure. The occurrence of this misconception increases rapidly after the lesson where the pupils learn how to ascertain a whole for a given fractional part of a set of discrete objects (e.g. if $3 / 5$ of a whole is 30 , what is the whole?), because the reversed order belongs to this type of tasks.

The bottom left bubble offers a misconception which is not so frequent, and results in subtracting $3 / 5$ from $30 / 5$. The respondent provides an explanatory commentary to this bubble: "The pupil subtracted the removed part of candies from the total amount of 30 candies, which he wrote as $30 / 5$, and did not realized that this is the whole, and thus equals $5 / 5$."

The author of the Concept Cartoon also provides a list of educational goals related to the problem she posed:

- to understand the relations between the parts and the whole;

- to learn and remember that if we have a fraction from something, we have to divide by the denominator, and multiply by the numerator, not vice versa;

- $\quad$ to realize that the fraction stands for some amount $(3 / 5$ of $30=18)$, and do not combine these notations $(30-3 / 5)$;

- to realize that the remainder cannot be bigger than the original amount;

- to consider that more different notations of results might exist here.

Summarized, the Concept Cartoon posed by the participant supplied us with a lot of information about her reasoning and pedagogical content knowledge. We can see that she knows various ways of solving the task, and also the most frequent pupils' misconception.

She reasons properly, also in accordance with open approach to mathematics (she realizes that there might be more ways of solving or more notations of the result). The only serious objection goes to her second educational goal: the effort to lead the pupils "to learn and remember that if we have a fraction from something, we have to divide by the denominator, and multiply by the numerator, not vice versa" would rather strengthen the just-procedural and non-conceptual view of the task, and could increase the occurrence of the reverse-order misconception.

\section{Discussion}

We can say that our results are in accordance with the results of the research that preceded our study. Looking at the results from the perspective of Concept Cartoons, we can see the importance of not considering respondents' answers apart from reasoning behind the answers, and the importance of observing the answers in complexity - the data excerpts in the 'Results' section together with Figure 6 and Figure 7 clearly illustrate this issue. Since Concept Cartoons offer several alternative viewpoints to comment on, they make the respondents to reason not only in the context of their "favourite" interpretation of the topic behind the picture, but also in the context of other interpretations - an activity which is a very important part of teachers' education, especially in case of primary school teachers and fractions (Behr et al., 1993; Lamon, 2006). On the other hand, Concept Cartoons can offer alternatives of different difficulty (of different levels of mathematical knowledge), which makes them polyvalent math tasks, a special class of open problems that proved their positive impact in (future) teachers' education (Hellmig, 2010; Nohda, 2000; Samková and Tichá, 2016c).

Generally said, in this contribution we offered an illustration of how Concept Cartoons could help in future primary school teachers' education: by perceiving Concept Cartoons as a representation of practice (Samková, 2017), the educators can study future teachers' responses to fictitious pupils' ideas or observe how future teachers create their own Concept Cartoons, and thus obtain information on various dimensions of teachers' knowledge (e.g. to what extent they have ideas on sources of misconceptions and errors).

Looking at the results from the perspective of the fractions topic, we can see the importance of focusing on proper grasping of the concept of the fraction, namely on the whole-and-parts relations. In accordance with previous research on primary school teachers' knowledge of fractions (e.g. Cramer and Lesh, 1988; Ma, 1999; Tichá and Hošpesová, 2013), analysis of the data collected during our study revealed various serious misconceptions that future primary school teachers employed in their reasoning, mainly handling fractions as an additive structure, identifying improperly the whole in a task, and handling fractions as named numbers.

Our data also revealed several respondents that saw the sources of errors just in linguistics but not in mathematics, a phenomenon which we know from our previous experience with future primary school teachers responding to Concept Cartoons (see Samková and Hošpesová, 2015). Nevertheless, the linguistics is an integral part of mathematics and cannot be treated separately, mathematics cannot be separated from its own language. Each mathematical topic has its own terminology and the way how it should be employed, the terminology is tied to the context of the topic in which it originated, and very often undergoes some changes when used in another context. For instance, the statement "Peter has 5 more books than Paul" originates in the context of natural numbers and refers to an additive structure, while the statement "Peter has $1 / 5$ more books than Paul" originates in the context of fractions and refers to a combination of multiplicative and additive structures. Both the statements have the same wording (only numbers differ), and one has to be able to distinguish the diverse contexts given by the numbers, to understand that the fraction $1 / 5$ refers to the whole that is stated in the statement after the conjunction "than". The responses given by the respondents S13 and S19 clearly show that these respondents are not aware of the reference to the whole that is given in the text which they comment on. In Czech language (which is the language of our long-term respondents) the syntax of the above mentioned statements differs only a little from the English syntax, the core of the problem stays the same. More details on the Czech case can be found in (Tichá and Macháčková, 2006), details on the English case e.g. in (Lamon, 2006). Talking of linguistics and mathematics, we must not forget to mention that the mathematical language often differs from the informal everyday language, and that this fact may become another source of mathematical misconceptions that look like linguistic ones (for illustrative examples see Kuřina, 1986).

In the referred study we also used Concept Cartoons in problem posing activities, we asked future primary school teachers to pose a problem that could be assigned to primary school pupils during a lesson on mathematics. Our illustrative example shows in detail what kinds of information such a task can provide, and how can it inform us about respondent's reasoning and pedagogical content knowledge. The results again confirmed the importance of problem posing in future teachers' education (Hošpesová and Tichá, 2015).

We are aware that the weak point of our study consists in size of the sample, and that the results cannot be generalized. But we 
hope that our study can become a source of an inspiration for other educators of teachers.

\section{Conclusion}

In this contribution we focused on the possibility to use an educational tool called Concept Cartoons as an instrument for observing how future primary school teachers reason about fractions. We used them in problem solving as well as in problem posing activities. From mathematics content perspective we concentrated on the concept of a fraction per se, which belongs to the primary school curriculum. As a part of the contribution we provided an extensive overview of how the concept emerges in the primary school classroom.

The main group of respondents consisted of future primary school teachers that had already completed the mathematics content course covering the topic of fractions.

Data collected during problem solving activities confirmed how the topic of fractions is difficult for future primary school teachers, and highlighted the significant difference between subject matter knowledge and pedagogical content knowledge that dominates this topic. Although the respondents had already studied the topics in detail within the content course, they were not able to respond properly to fictitious primary school pupils' ideas about fractions that were assigned to them on a worksheet with a Concept Cartoon - only minority of respondents mastered to respond properly to all presented statements on the parts-andwhole decision. Similar trends appeared even in an additional group of respondents, future lower-secondary school teachers from two other universities.

Contrarily, the illustrative example collected as a product of problem posing activities of one of the future primary school teachers showed how Concept Cartoons may help to elaborate a wide range of pedagogical content knowledge: the author of the cartoon posed an appropriate mathematical problem, presented several ways of its solving together with several frequent possible pupils' misconceptions, and justified all of them properly.

The results confirmed that Concept Cartoons may be employed as a valuable universal tool in future teachers' education: as an environment for problem posing activities as well as an instrument for qualitative assessment of subject matter knowledge and pedagogical content knowledge.

\section{Acknowledgements}

This article was supported by the Czech Science Foundation under Grant 'Enhancing mathematics content knowledge of future primary teachers via inquiry based education', project No. 14-01417S. This article was supported by RVO 67985840.

\section{References}

Behr, M., Lesh, R., Post, T., Silver, E. (1983) 'Rational number concepts', in Acquisition of mathematics concepts and processes, New York: Academic Press, pp. 91-125.

Brlicová, V., Vémolová, R., Zelený, P. (2016) Testy 2017 z matematiky pro žáky 5. a 7. tř́d ZŠ, Brno: Didaktis.

Cramer, K., Lesh, R. (1988) 'Rational number knowledge of preservice elementary education teachers', in Proceedings of PME 88, DeKalb, Il: PME, pp. 425-431.

Dabell, J., Keogh, B., Naylor, S. (2008) Concept Cartoons in Mathematics Education, Sandbach: Millgate House Education. Depaepe, F., Torbeyns, J., Vermeersch, N., Janssens, D., Janssen, R., Kelchtermans, G., Verschaffel, L., Van Dooren, W. (2015) 'Teachers' content and pedagogical content knowledge on rational numbers: a comparison of prospective elementary and lower secondary school teachers', Teaching and Teacher Education, vol. 47, pp. 82-92. http://dx.doi.org/10.1016/j. tate.2014.12.009

Divíšek, J., Hošpesová, A., Kuřina, F. (1999) Svět čísel a tvarů. Matematika pro 4. ročník, Praha: Prometheus.

Hellmig, L. (2010) 'Effective 'blended' professional development for teachers of mathematics: design and evaluation of the "UPOLA"-program', in Proceedings of CERME 6, Lyon, France, pp. 1694-1703.

Hoskovcová, S., Krejčová, L. (2015) 'Changes of academic efficacy in the course of education levels transition', in Proceedings of ERIE 2015, Prague, pp. 174-180.

Hošpesová, A., Tichá, M. (2015) 'Problem posing in primary school teacher training', in Mathematical problem posing, New York: Springer, pp. 433-447. http://doi.org/10.1007/978-14614-6258-3

Hošpesová, A., Žlábková, I. (2016) 'Assessment in inquiry based education in primary mathematics', in Proceedings of ERIE 2016, Prague, pp. 194-201.

Hruša, K., Vyšín, J. (1964) Vybrané kapitoly z metodiky vyučováni matematice na základní devitileté škole, Praha: SPN. Keogh, B., Naylor, S. (1999) 'Concept cartoons, teaching and learning in science: an evaluation', International Journal of Science Education, vol. 21, no. 4, pp. 431-446. http://doi.org/ 10.1080/095006999290642

Koman, M., Kuřina, F., Tichá, M. (1997) Matematika pro 5. ročník základní školy, učebnice, Praha: MÚ AV ČR.

Kuřina, F. (1986) 'O jazycích školské matematiky', Pokroky matematiky, fyziky a astronomie, vol. 31, no. 5, pp. 277-281.

Lamon, S.J. (2006) Teaching fractions and ratios for understanding: Essential content knowledge and instructional strategies for teachers, Mahwah, NJ: LEA. http://doi.org/10. 4324/9781410617132

Littler, G.H., Taylor-Basil, V. (1999) 'Children's experiences in life - their benefit to the learning of mathematics', in Proceedings of SEMT 99, Prague, pp. 76-79.

Ma, L. (1999) Knowing and teaching elementary mathematics, Mahwah, NJ: Erlbaum.

Nohda, N. (2000) 'Teaching by open-approach method in Japanese mathematics classroom', in Proceedings of PME 24 (Vol. 1), Hiroshima, Japan, pp. 39-53.

Novotná, J. (2016) 'Heuristic strategies in solving of mathematical problems at school', in Proceedings of ERIE 2016, Prague, pp. 429-439.

Novotná, J., Eisenmann, P., Přibyl, J., Ondrušová, J., Břehovský, J. (2014) 'Problem solving in school mathematics based on heuristic strategies', Journal of Efficiency and Responsibility in Education and Science, vol. 7, no. 1, pp. 1-6. http://doi. org/10.7160/ eriesj.2014.070101

Patáková, E. (2013) 'The quality of mathematical problems - evaluation and self-evaluation', Journal of Efficiency and Responsibility in Education and Science, vol. 6, no. 3, pp. 143154. http://doi.org/10.7160/eriesj.2013.060302

Samková, L. (2016a) 'Didaktické znalosti obsahu budoucích učitelů 1. stupně základní školy před studiem didaktiky matematiky', Scientia in educatione, vol. 7, no. 2, pp. 71-99.

Samková, L. (2016b) Using Concept Cartoons to investigate future teachers' knowledge-new findings and results. Research report presented at the 3rd ERME Topic Conference, October 2016, Berlin, Germany.

Samková, L. (2017) 'Concept Cartoons as a representation 
of practice', in Mathematics Teachers Engaging with Representations of Practice. ICME-13 Monograph, New York: Springer, in press.

Samková, L., Hošpesová, A. (2015) 'Using Concept Cartoons to investigate future teachers' knowledge', in Proceedings of CERME 9, Prague, pp. 3241-3247.

Samková, L., Tichá, M. (2015) 'Investigating future primary teachers' grasping of situations related to unequal partition word problems', Quaderni di Ricerca in Didattica (Mathematics), vol. 25, no. 2, pp. 295-303.

Samková, L., Tichá, M. (2016a) 'Developing open approach to mathematics in future primary school teachers', in Proceedings of ERIE 2016, Prague, pp. 494-501.

Samková, L., Tichá, M. (2016b) 'Developing views of proof of future primary school teachers', in Proceedings of Aplimat 2016, Bratislava, pp. 987-998.

Samková, L., Tichá, M. (2016c) 'On the way to develop open approach to mathematics in future primary school teachers', Journal of Efficiency and Responsibility in Education and Science, vol. 9, no. 2, pp. 37-44. http://doi.org/10.7160/ eriesj.2016.090202

Samková, L., Tichá, M. (2017a) 'Observing how future primary school teachers reason and generalize: the case of number triangles and Concept Cartoons', in Proceedings of Aplimat 2017, Bratislava, pp. 1354-1368.

Samková, L., Tichá, M. (2017b) 'Observing how future primary school teachers reason about fractions', in Proceedings of ERIE 2017, Prague, pp. 363-371.

Singer, F.M., Ellerton, N.F., Cai, J. (2015) Mathematical problem posing, New York: Springer. http://doi.org/10.1007/978-1-46146258-3

Tichá, M., Hošpesová, A. (2013) 'Problem posing as a motivational tool in improving primary school teacher knowledge', Quaderni di Ricerca in Didattica (Mathematics), vol. 23, no. 1, pp. 307-316.

Tichá, M., Macháčková, J. (2006) Rozvoj pojmu zlomek ve vyučování matematice, Praha: JČMF.

Tirosh, D. (2000) 'Enhancing prospective teachers' knowledge of children's conceptions: the case of division of fractions', Journal for Research in Mathematics Education, vol. 31, no. 1, pp. 5-25. http://doi.org/10.2307/749817 